\title{
Prishtina-Belgrade Technical Agreement Promotes Political Dialogue but with Delay of its Implementation It Sharpens Ethnic Divisons
}

\author{
Urtak Hamiti \\ Professor at "lllyria College" \\ Prishtina Kosovo and PhD Candidate at the University of Tirana, Albania \\ urtaku@gmail.com
}

\begin{abstract}
The Technical Agreement between Prishtina and Belgrade, brokered by European Union in April 2013, was hailed as a milestone in the process of normalization of relations between the two countries as well as unblocking the path of both Kosovo and Serbia towards European Union. The dialogue held a promise as a vehicle which, in conjunction with bilateral pressure on both sides by $E U$ and a tailored enlargement process, could finally lead to normalization of relations between Kosovo and Serbia. However, most of the deadlines set up in the implementation plan of the Agreement have been stepped over. This delay in implementation combined with the victory of "Serbian List", Kosovo Serb political party backed heavily by Belgrade Government, in the last general elections in Kosovo, have brought into jeopardy two of the main targets of the Technical agreement as a vehicle to a broader and more important political dialogue between Kosovo and Serbia as well as integration of local Kosovo Serbs into institutions of the state of Kosovo. This paper argues that Germany, United Kingdom and USA need to be more directly engaged in the process to pressure both sides to fulfill what was agreed in April 2013. It is a prevailing belief among many analysts that the only peaceful acceptable outcome depends on full integration of Kosovo Serbs in Kosovo's state institutions, full normalization of relations between Prishtina and Belgrade, mutual recognition, and rewarding Kosovo by suspending the visa regime for EU countries for citizens of Kosovo. Delay in implementation, loss of pace and interest of EU in this process, is leading to sharpening of ethnic divisions in Kosovo and increasing the numbers of those who oppose dialogue on both sides.
\end{abstract}

Keywords: Kosovo, Prishtina-Belgrade dialogue, EU Foreign Policy, Western Balkans, Albanian-Serb divisions

\section{CHRONOLOGY OF EVENTS}

Following the Declaration of the Independence of the Republic of Kosovo, February $17^{\text {th }} 2008$, European Union, especially the countries that have recognized Kosovo's independence have tried to find a way to open a dialogue between Prishtina and Belgrade authorities to try to bridge the political divide that exists between Kosovo and Serbia even today. This initiative coming from EU officials was further strengthen by the fact that Kosovo has been recognized, in a very brief period by more than 100 UN Member States in all of the continents of the Globe. Since spring 2011, EU has supported a technical dialogue between the governments of Kosovo and Serbia, firstly aiming to improve the living conditions of the Serbs living in Kosovo, and secondly aiming to increase the dialogue to other political options and discussions that would cover matters such as recognition of each other countries documents, freedom of movement, with the final prize of reaching a political sustainable settlement between Kosovo and Serbia in their path toward EU integration processes.

Technical dialogue between Prishtina and Belgrade authorities began on March $8^{\text {th }} 2011$ via mediation of EU in Brussels with full support of United States of America. First four rounds of dialogue resulted in no credible outcomes but they set the principles and the framework for future negotiations. In the fifth round of dialogue, on July $2^{\text {nd }} 2011$, an agreement was reached on freedom of movement of citizens across territories of Kosovo and Serbia with the use of ID cards, rather than passports. ${ }^{1}$ This decision was not in collision with the current Constitution of the Republic of Serbia, which still in its preamble states that "Province of Kosovo and Metohija is part of the territory of Serbia, holds a position of substantial autonomy as part of sovereign state of Serbia therefore it is obliged to represent and protect the interest of Serbia in Kosovo

\footnotetext{
1 Brussels , July 2nd 2011, "Report on political and technical dialogue with Provisional institutions in Pristina", Government of Serbia, full text provided on 24th of April 2013 
and Metohija in all of its internal and external decisions". ${ }^{1}$ Kosovo's authorities viewed this decision in a more pragmatic way, since their interest was the freedom of movement of Kosovo's citizens through the territory of the Republic of Serbia without any kind of hindrance.

After this initial agreement there were several other agreements on the technical level regarding cadastral records and other individual documents, customs duties, mutual recognition of university degrees. The most important technical agreement was reached on border issues, more precisely on Integrated Border Management-IBM, reached on December $2^{\text {nd }} 2011$. According to this agreement both sides have agreed to have their representatives in all borders crossings between Kosovo and Serbia including representatives of EULEX Mission. Regarding this decision a special Technical Protocol was established and signed between the parties in Prishtina on February 23 2013.

In the ninth round of negotiations an agreement has been reached, on February $24^{\text {th }} 2012$ following persistent insistence of the EU, on allowing Kosovo to take part in regional integration processes. This came not without a price for the authorities of Kosovo which had to accept that their representation in regional forums will be "Republic of Kosovo" followed by a footnote stating that "the status in the nomination does not prejudge final status and is in accordance with the Resolution 1244 of UN Security Council and the Decision of the International Court of Justice regarding Kosovo's Declaration of Independence". Serbian side considered that it had protected their Constitution while Kosovo side was more interested in taking part and being integrated as much as possible in the regional cooperation institutions, barring in mind that these are necessary steps to reaching EU cooperation institutions.

Perhaps the largest achievement of the technical dialogue between Prishtina and Belgrade was that it has step by step lowered the burden of Albanian and Serb conflicts from previous century that was resting on the shoulders of political representatives of both Prishtina and Belgrade. Moreover, this process has helped citizens of Kosovo and Serbia, both individual and businesswise, to have no obstacles in their intentions to travel or invest in Kosovo or Serbia.

Following Parliamentary elections in Serbia in May 2012 a new Government was formed, and for the first time since the end of Kosovo war the issue of Kosovo was not the predominant matter in the campaign; it was the economy. Therefore, the technical dialogue was moved to a more political starting from $19^{\text {th }}$ October 2012, which resulted in an agreement of appointing "Liaison Officials" of Kosovo and Serbia in Prishtina and Belgrade, on $7^{\text {th }}$ of November 2012. For Serbian side this was just another political decision, while Kosovar side considered this decision another step forward to Serbian formal recognition of Kosovo as an independent state. Kosovar side also showed a very pragmatically decision to put the official offices of the Representative of Kosovo to Belgrade in the building of EU official representation in Serbia.

Following further high level political dialogue between Kosovo's PM Hashim Thaci and Serbian PM Ivica Dacic, facilitated by EU's representative for Foreign and Security Policies Catherine Ashton, on $19^{\text {th }}$ of April 2013 a formal agreement has been reached between the sides outlining the steps of "normalizing the relations between Prishtina and Belgrade". The agreement came just in time as on Monday, 22th of April, was the meeting of EU's General Affairs Council and Foreign Affairs Council. In both meetings Catherine Ashton briefed Foreign Ministers of EU's 27 countries on the current status and future steps in negotiations between Kosovo and Serbia. At stake was whether to open negotiations on Serbia becoming a possible EU member and a possible Stabilization and Association Agreement (SAA) between Kosovo and EU. As it happens, General Affairs Council of the European Commission formally recommended to EU Member States that EU accession negotiations with Serbia and negotiations on an SAA with Kosovo be opened.

Messages of congratulations by a number of very important world politicians followed the Agreement in the EU facilitated dialogue on the normalization of relations between Kosovo and Serbia. Among others they included President of European Council Herman Van Rompuy, President of European Commission Jose Manuel Barroso, Commissioner for Enlargement and Neighborhood Policy Stefan Fule, US Secretary of State John Kerry, UN Secretary General Ban Ki-Moon, NATO's Secretary General Anders Fogh Rasmussen.

The 15 Points Plan signed between PM Thaci and PM Dacic witnessed by Catherine Ashton include several very important items. In accordance with the Plan all Serb Police officers, including those of northern Kosovo, are to be integrated into the Republic of Kosovo Police Force, while all other security structures are to be dissolved. A regional police commissioner, who will belong to Serb minority in Kosovo, is to be appointed for the four predominantly Serb ethnic group municipalities in "northern Kosovo". All legal institutions of the Serbs are to be integrated into the legal system of Kosovo. The court of

\footnotetext{
${ }^{1}$ Current Constitution of the Republic of Serbia
} 
appeal in Prishtina is to establish a branch court in Northern Mitrovica to deal with cases of the communities with a Serb majority. The judges in district courts will be predominantly made up of Serbs. Elections in Serb predominant areas, local and general, are to be supported by OSCE, conform to the legislation of Kosovo and international standards. In addition, neither Belgrade nor Prishtina are to block each other on their path toward EU. ${ }^{1}$

After the agreement reached between Kosovo and Serbia came the talks for the Implementation Plan of the Agreement. From $19^{\text {th }}$ of April 2013 until $24^{\text {th }}$ of July 2013 thirteen rounds of talks were held on this subject alone. ${ }^{2}$ Implementation of the Agreement was not able to be achieved yet for several issues mainly related to the status of Kosovo and the manner that Serbia views Kosovo. For authorities in Belgrade the implementation had to be in accordance with "status neutral" policy while authorities in Prishtina considered that implementation is not possible without establishment of full sovereignty in all of Kosovo's territory.

Belgrade authorities particularly remain persistent in the creation of the Association of Serbian Municipalities in Kosovo, as foreseen in the Brussels Agreement, a body which will have its Assembly, Executive Committee, aid funds (meaning from Serbia). Kosovo's authorities have agreed that Serbian Municipalities in Kosovo can create their Association which will be in full compliance with the Laws of the Republic of Kosovo.

Authorities in Belgrade were instrumental in convincing local Kosovo Serbs to take part in local and governmental elections in 2014. Authorities in Belgrade insisted in appointing new local Serb politicians at local and governmental level that would be loyal to Belgrade. In that attempt they have achieved success and now part of Kosovo's Government is local Serb political entity "Srpska Lista" (Serbian List). The aim of authorities in Belgrade was to have influence in highest levels of decision making policies in Kosovo through a political entity that answers to Belgrade at all times. Authorities in Prishtina were not bothered by this fact since by the Constitution of Kosovo Serbian Minority has a guaranteed participation in the Government. But the implementation of Brussels Agreement needs more.

\section{CONCLUSIONS}

In the following processes and relations between Prishtina and Belgrade the most significant role remains the one of United States and Germany, as leaders of Western Countries, NATO, EU influence, and future OSCE chairmanship. European perspective and dynamics of the process of integrations will remain on the willing of EU's institutions of resolving opened questions sooner rather than later. EU cannot afford another frozen conflict like Cyprus/Northern Cyprus or Armenia/ Azerbaijan Nagorno Karabakh situation to be present in volatile Balkans. In case of Nagorno-Karabakh the situation remains explosive. In the summer of 2014, while the international community was focused on the crisis in Ukraine, hostilities escalated in this region yet again. Over the years Azerbaijan has used its energy revenues to improve its military capabilities spending 3 billion USD per year, or 5\% of GDP for military purposes. To match Azerbaijani capabilities, Armenia equipped itself with drones. ${ }^{3}$ So, the seeming comfort of status quo in frozen conflicts should not be taken for granted.

One often suggested possibility is that even Slobodan Milosevic hoped to partition Kosovo on terms favorable to the Serb minority, and favorable to the Serb control of historical and religious sites and mineral wealth. There is no evidence, however, that Serb officials suggested this possibility-not at Rambouillet Talks and not during the war of 1998-1999. However, there is evidence that Milosevic had pushed the plan for the partitioning of Kosovo during negotiations before the war. ${ }^{4}$ Many observers before and during the war speculated that partitioning might be the "last stand" objective. ${ }^{5}$ Serbian military employed a greater pattern of physical destruction to Kosovar Albanian property in certain areas in northern part of

\footnotetext{
1 Predrag Jurekovic, Austrian National Defence Academy Vienna, "Kosovo Agreement-Implementation as Litmus test", IFK Monitor International July 2013, pg 2

2 Dragan Djukanovic, Odnosi izmedju Beograda I Prishtine, Izvorni Naucni Rad Jul 2013, Beograd, BiBlid Vol. LXV, br 3, pg 377

3 Elena Pokalova, "Conflict Resolution in Frozen Conflicts: Timing in Nagorno-Karabakh", Journal of Balkan and Near Eastern Studies, 20 December 2014, pg 82

4 Carlotta Gall, "Serbs Fear Puts Segregation back on the table in Kosovo", New York Times, 26th of August 1999, p A1

5 Jonathan Steele, "Kosovo Crisis: Province at Stake as Milosevic considers spoils of war", $9^{\text {th }}$ of June 1998 Guardian, pg11; Vladimir Kuznechevskiy "Primakov may have suggested Kosovo Partition to Milosevic", Moscow Rossiyskaya Gazeta, 31 st of March 1999, and also Barry R. Posen "The War for Kosovo", International Security, Vol 24, No.4 (Spring 2000) pg 45-46
} 
Kosovo, hence some observers noted an apparent pattern of expulsion of Albanians concentrated in these same areas and inferred a partition motive. ${ }^{1}$

Authorities of Kosovo have shown capacity in building a society with multiethnic and multicultural elements in all parts of Kosovo and there is no doubt that that can be achieved in the northern part as well. They have also shown a great what one might call, generosity in providing additional rights for all minorities in Kosovo, although last census has shown that Kosovo is $92 \%$ Albanian populated country.

On the other hand Serbian side has taken steps similar to the policies of the 90s in the last century by which Belgrade is the political, intellectual, spiritual, capitol of all Serbs as well as protector of their rights in all of the countries that Serbs live, but comprise no more than a national minority.

Delay of implementing Brussels Agreement will prove a severe mistake for all sides. Having in mind the relations between Kosovo and Serbia, open issues between two countries and nations; it is hard to believe that progress can be done without firm involvement of United States and EU headed by Germany to insure that all sides deliver on their promises.

EU integration policy towards Kosovo and Serbia must continue entailing clear conditions with regard to Kosovo-Serbia dialogue. United States and EU should make Belgrade responsible for implementing Brussels Agreement in northern Kosovo as they did in the case of Erdut Agreement in Croatia in 1998.

Kosovo's authorities should make sure to fulfill all obligations and provide more favors to northern Kosovo Serbs than those that southern Kosovo Serbs already have.

Any other scenario could bring out in the open ethnic divisions in Kosovo and the Balkans which is in no one's interest.

\section{REFERENCES}

[1] Brussels , July 2nd 2011, "Report on political and technical dialogue with Provisional institutions in Pristina", Government of Serbia, full text provided on 24th of April 2013

[2] Current Constitution of the Republic of Serbia

[3] Predrag Jurekovic, Austrian National Defence Academy Vienna, "Kosovo Agreement-Implementation as Litmus test", IFK Monitor International July 2013, pg 2

[4] Dragan Djukanovic, Odnosi izmedju Beograda I Prishtine, Izvorni Naucni Rad Jul 2013, Beograd, BiBlid Vol. LXV, br 3 , pg 377

[5] Elena Pokalova, "Conflict Resolution in Frozen Conflicts: Timing in Nagorno-Karabakh", Journal of Balkan and Near Eastern Studies, 20 December 2014, pg 82

[6] Carlotta Gall, "Serbs Fear Puts Segregation back on the table in Kosovo", New York Times, 26 th of August 1999, p A1

[7] Jonathan Steele, "Kosovo Crisis: Province at Stake as Milosevic considers spoils of war", 9 th $^{\text {th }}$ June 1998 Guardian, pg11; Vladimir Kuznechevskiy "Primakov may have suggested Kosovo Partition to Milosevic", Moscow Rossiyskaya Gazeta, 31st of March 1999, and also Barry R. Posen "The War for Kosovo", International Security, Vol 24, No.4 (Spring 2000) pg 45-46

[8] Charles Bremmer, "NATO expects Serb Partitioning Gambit", Times, London, 9th of April 1999

\footnotetext{
${ }^{1}$ Charles Bremmer, "NATO expects Serb Partitioning Gambit", Times, London, 9th of April 1999
} 